\title{
Tourism Intensity in the NUTS III Regions of Slovakia
}

\author{
Róbert Štefko \\ University of Prešov, Faculty of Management, Slovakia \\ Petra Vašaničová \\ University of Prešov, Faculty of Management, Slovakia \\ Eva Litavcová \\ University of Prešov, Faculty of Management, Slovakia \\ Sylvia Jenčová \\ University of Prešov, Faculty of Management, Slovakia
}

\begin{abstract}
Although Slovakia is not yet well known on the international tourism market, regional specificity and variability predetermine the Slovak area for the development of tourism, which has become increasingly popular in recent years. The aim of this paper is to assess and visualize the tourism intensity in the NUTS III regions of Slovakia. Therefore, we calculate indicators such as Defert index, tourism intensity rate, Charvat index, index of territorial density of tourism, tourist density rate, and index of land use. Results show that Bratislava Region had the biggest volume of tourism intensity; the second position occupied the Zilina Region; and the Presov Region ranked third. We found out that there has been a positive change in the development of almost all tourism intensity indicators during the period from 2001 to 2016. Based on the values of the calculated indicators, it seems that Slovakia still has the opportunity to develop tourism sector in all regions.
\end{abstract}

Key words: Tourism, Slovakia, NUTS III regions, Tourism intensity

JEL Classification: Z32

\section{Introduction}

Tourism is often considered a global phenomenon. Its significance is evident what results from its penetration into society, politics, culture, and especially into the economy. Tourism destination is a natural entity that has unique characteristics different from other destinations in terms of conditions of tourism development (Királ'ová, \& Straka, 2013, p. 9; Királová, \& Pavlíčeka, 2015, p. 358). From the point of view of international tourism, the entire country, some region or city may be considered to be the destination (Pásková, \& Zelenka, 2002 in Királ'ová, \& Straka, 2013).

Slovakia is a country with great potential for tourism. Thanks to its central position in Europe, Slovakia has become a crossroads of trade and cultural routes and political interests, 
which has also been reflected in its cultural wealth (Gregorová, 2014). In many regions of Slovakia, tourism is considered to be a key sector that should ensure the development of the region. A great part of the Slovak territory has good natural, cultural and historical conditions for tourism development, which includes natural and protected areas, national parks, mountains, lakes, waterfalls, valleys, caves, gorges, thermal and mineral swimming pools, castles, mansions, chateaus, or water reservoirs (Fil'arská, Vozárová, \& Kotulič, 2017). Also the religious tourism and notably pilgrimage tourism started to play a significant role in regional development in Slovakia (Štefko, Királ'ová, \& Mudrík, 2015, p. 428). Regional specificity and variability predetermine the Slovak area for the development of tourism, which has become increasingly popular in recent years. However, there are differences between the regions in terms of the material and technical basis, which is a precondition for the tourism development.

Slovakia is a relatively new independent state, which is not very well known in the international tourism market. Therefore, domestic tourism plays the crucial role in the Slovak tourism development form the long-term perspective (Gajdošíková, Gajdošík, Kučerová, \& Magátová, 2016). "Geography is the ideal discipline for studying the global tourism industry. Given the inherently spatial aspects of tourism, geographers have contributed significantly to academic tourism studies" (Che, 2017). According to the Eurostat database, in 2017, the population of Slovakia was estimated to be $5,442.79$ thousand. Its area is $49,035 \mathrm{~km}^{2}$ with a population density of approximately 110 inhabitants per $\mathrm{km}^{2}$. In order to maintain Slovakia's position as the tourism destination, it is necessary to continuously improve the quality of its services; to realize a wide range of communication and promotional activities. Performing mentioned activities effectively requires recognition of the importance of tourism in the given country.

At present, the issue of tourism development is linked to the sustainable tourism, which is defined by the UNWTO (UNWTO, 2005, p.11-12) as "tourism that takes full account of its current and future economic, social and environmental impacts, addressing the needs of visitors, the industry, the environment and host communities”. Specific features and selected factors of consumer behaviour in tourism must be taken into account too (Hroncova, Birknerova, \& Janovska, et al., 2012). The concept of the sustainable tourism is connected with the term of tourism carrying capacity that is defined as "the maximum number of people that may visit a tourist destination at the same time, without causing destruction of the physical, economic, socio-cultural environment and an unacceptable decrease in the quality of visitors" (UNWTO, 1981, p. 4). It follows that it is important to focus on the development and recommendation of the suitable measures and tools for sustainable tourism development with the active participation of all Slovak regions.

To write this article, we were motivated by the publication of General Commission for Sustainable Development (Gauche, 2017) in which were provided measurements of tourism intensity with respect to the impact of demographic changes caused by tourism on the environment in tourist destinations. Despite the fact that much more small municipalities have been evaluated in the above-mentioned publication, the aim of this paper is to assess and visualize the tourism intensity in the eight NUTS III regions of Slovakia.

The remainder of this paper is structured as follows. Section 2 describes Slovak NUTS III regions from the point of view of tourism. In Section 3 are presented the data and the methodology. In Section 4 we discuss results and section 5 concludes. 


\section{Description of Slovak NUTS III regions from the point of view of tourism}

Since 1996 regional level of Slovak governance represents eight self-governing regions - NUTS III (Bucher, \& Nováková, 2015), which include Bratislava, Trnava, Trencin, Nitra, Zilina, Banska Bystrica, Presov and Kosice Region. These regions differ from each other; therefore, in Table 1 we present selected indicators from 2016 that are important for regions' comparison in tourism. We can summarize briefly that even though the Bratislava Region has the smallest area; it is the most attractive for tourists (Graph 1). The number of overnight stays is very similar in Zilina and Presov Region, and in Trnava and Trencin Region. In 2016, the lowest number of arrivals was recorded in Nitra Region, but this region nevertheless recorded more overnight stays than Kosice Region which ranked fifth within total arrivals.

Table 1

Selected indicators of Slovak NUTS III regions in 2016

\begin{tabular}{|c|c|c|c|c|c|c|}
\hline 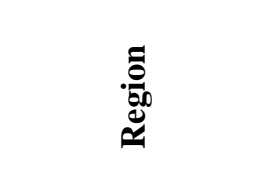 & 灭 & 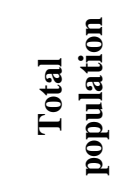 & 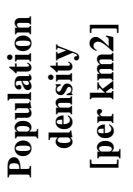 & 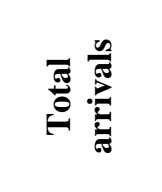 & 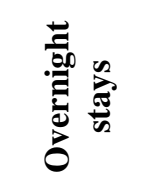 & 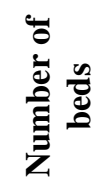 \\
\hline Bratislava & $2,052,616$ & 633,288 & 0.309 & $1,386,283$ & $3,000,449$ & 27,920 \\
\hline Trnava & $4,146,344$ & 559,697 & 0.135 & 318,524 & $1,203,899$ & 15,795 \\
\hline Trencin & $4,501,822$ & 589,935 & 0.131 & 322,020 & $1,274,486$ & 15,259 \\
\hline Nitra & $6,343,735$ & 682,527 & 0.108 & 298,829 & 828,062 & 16,190 \\
\hline Zilina & $6,808,524$ & 690,434 & 0.101 & 975,536 & $2,777,136$ & 40,057 \\
\hline Banska Bystrica & $9,454,003$ & 653,024 & 0.069 & 520,895 & $1,614,400$ & 21,518 \\
\hline Presov & $8,972,971$ & 820,697 & 0.091 & 854,528 & $2,713,587$ & 32,291 \\
\hline Kosice & $6,754,330$ & 796,650 & 0.118 & 347,014 & 726,401 & 23,188 \\
\hline
\end{tabular}

Source: Authors processing by using data of Statistical Office of the Slovak Republic

Graph 1

Number of arrivals at tourism accommodation establishments of Slovak NUTS III regions in 2016

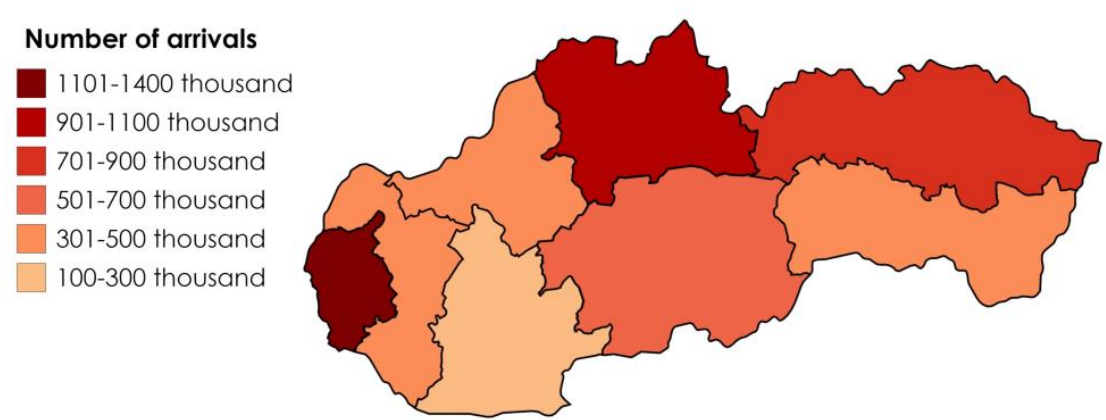

Source: Authors processing by using data of Statistical Office of the Slovak Republic

Based on the Slovakia.travel portal (2015), which is the official promotional and information system of Slovak tourism, we describe the basic information on tourism opportunities and places to go within the NUTS III regions of Slovakia. The description shows that Slovakia is indeed a country with a high potential for tourism development. 
In Bratislava Region, the capital city Bratislava is situated with the numerous attractions around from which the greatest are cultural and historical monuments, i.e., ruins of Devín Castle, Plavecký Castle, Pajštún Castle, The Red Stone Castle; the Morava Cycling Route; the Danube International Cycling Route; the Gallery of Contemporary Art in Cunovo; the cruises on the River Danube; the Small Carpathians Wine Route; the Sunny Lakes and aqua park in Senec; and the Modra Ceramics. There are performing many activities of creative tourism in this region (Štefko, \& Šteffek, 2017).

The metropolis of Trnava Region is the city of Trnava which has the historic core with abundant sacral monuments. In this Region, there are situated spas Piešt'any and Smrdáky; castles the Sharp stone, the Korlátka, the Good Water, the Smolenice Castle; the town Skalica with cultural and historical monuments; Basilica of Šaštím; thermal swimming pools in Dunajská Streda, Vel'ký Meder, Topol'níky; water mills on the river Little Danube; mountain range Small Carpathians.

Trencin Region is known by the Trenčín Castle; the Bojnice Chateau which is the most visited and most beautiful historic monuments in Slovakia; ruins of the Beckov Castle, the Čachtice Castle, the Topol'čany Castle, the Uhrovec Castle; mineral and thermal springs within spas of Trenčianske Teplice, Bojnice, and Nimnica.

Nitra which is the metropolis of the Nitra Region is the oldest town in Slovakia. In the vicinity are ancient churches Dražovce, Kostol'any pod Tribečom; the Gýmeš and the Hrušov Castle; the Manor House Topol'čianky; thermal swimming pools in Štúrovo, Komárno, Patince. Most popular is the exposition area Agrokomplex.

Within the Zilina Region, the town Martin has the most significant cultural and historical monuments. Most beautiful is the Orava Castle; ruins of the medieval Strečno Castle, the Old Castle, the Lietava Castle, the Hričovský Castle, the Súl'ovský Castle, the Likava Castle, the Liptovský Castle; the UNESCO monument of folk architecture Vlkolínec; wooden churches at Saint Cross, Tvrdošín, Leštiny, Istebné. Spa treatment is provided in Rajecké Teplice, Turčianske Teplice, and Lúčky. There are mountains Small Fatra, Big Fatra, Choč Mountains, West Tatras, Low Tatras with ski centres in Vel'ká Rača, Vrátna, Zuberec, Ružomberok, and Jasná; caves; reservoirs; and aqua parks Tatralandia, Oravice, Bešeňová.

The region of Banska Bystrica is known for the rich mining history in Banská Bystrica, Banská Štiavnica that is UNESCO monument, and Kremnica. Popular are mountains Low Tatras with ski resorts in Donovaly and Chopok SOUTH; the Čiernohorská forest railway; the Harmanecká Cave and the Bystrianska Cave; castle ruins in Fil'akovo, Divín, Blue Stone, Čabrad'; spas in Dudince, Kováčová, Sklené Teplice, and Sliač.

Prešov, the third biggest town of Slovakia, is the metropolis of Presov Region. In this region, High Tatras and within them the Tatra National Park is the most spectacular and most visited area. Well-known is the town Bardejov which is the UNESCO monument and spa Bardejovské kúpele situated near this town. In this region the city marketing plays the significant role with a great impact on tourism and income sources (Štefko, Bačík, \& Fedorko, 2017). The Manors Strážky; the Red Monastery, the Kežmarok Castle, the Lubovňa Castle; the Spiš Castle that is the biggest castle in the Central Europe; the Pieniny National Park with primeval vegetation of the Eastern Carpathian Mountains; the primeval forests of Stružica, Rožok and Havešová in the Bukovec Mountains and the primeval forest of Kyjov in the Vihorlat Mountain belong to the UNESCO list of world natural heritage; the Slovak Paradise; 
the town Levoča with the biggest wooden altar in the world; the ecclesiastical town Spišská Kapitula and the Gothic church in Žehra which are also included into the UNESCO monuments; or the Museum of Modern Art of Andy Warhol in Medzilaborce are the greatest attractions in this region.

The second biggest town of Slovakia is Košice that is the metropolis of Kosice Region with many cultural and historical monuments. A city promotion activities became very successful there (Hagyari, Bačík, \& Fedorko, 2016). Numerous caves and abysses which are included in the UNESCO monument list belong to the Slovak Karst National Park. There is the Krásna Hôrka Castle; the Betliar Manor House; many churches; the Gothic Route; Tokai area known for the excellent Tokai wine; water reservoir the Zemplínska Šírava; well-known caves such as the Ochtinská Aragonite Cave, the Dobšinská Ice Cave, the Domica Cave, the Jasovská Cave, the Gombasecká Cave; the geyser of Herl'any; the Vinianske Lake; the Eye of the Sea; the Košice Zoo in the local city part of Kavečany.

\section{Data and Methodology}

The tourism-accommodation function of the region, which reflects the level of the network development of accommodation establishments, is evaluated by various quantitative indicators. In this paper, we look into the intensity of tourism in the eight self-governing regions (NUTS III) of Slovakia, which include Bratislava, Trnava, Trencin, Nitra, Zilina, Banska Bystrica, Presov and Kosice Region. Motivated by the study of Dumbrovská, \& Fialová (2014) and Királová, \& Hamarneh (2016) we use indicators which are functions of the number of tourists, their average length of stay, the size of the local population and the area of the destination (Harrison, 1992). We obtain the required data from the database of the Statistical Office of the Slovak Republic. Our dataset which consists of annual data of the period from 2001 to 2016 we process and analyze in the form of tables, graphs, and chart maps.

The aim of our analysis is to answer the two main questions concerning the development of tourism in the regions of Slovakia. First, we want to prove that regions with a larger number of visitors also have more beds in accommodation establishments, for what we use Pearson's correlation coefficient. Second, we want to find out which three regions of Slovakia have the highest tourism intensity. Third, we want to find out whether there has been a positive change in the development of studied indicators, i.e., whether the values of indicators in the period from 2001 to 2016 have increased. Because of this, the differences between the values of selected indicators in 2016 and 2001 were calculated. In the following subsections, we describe six indicators that we use to describe tourism intensity. It must be noted that all described indicators have limitations resulting from the facts that tourist flows are seasonal; and tourism activity tends to be concentrated in specific geographical areas (Louis, 2004).

\subsection{Defert index}

As is stated in Marković, Perić, Mijatov, Doljak, \& Žolna (2017) and in Potts, \& Uysal (1992), in 1967, French geographer Pierre Defert was first who put into practise indicator that takes into account relationship between accommodation capacities and the number of inhabitants of a given destination. Defert function $(D F)$ or tourist function index (Sezgin, \& 
Gumus, 2016) expresses the number of bed places in accommodation establishment in a given region $(L)$ per the number of population $(P)$ of an entire region and is given by

$$
D F=\frac{L \cdot 100}{P} .
$$

In Table 2, there are described meanings of various values of Defert function. The function assumes a direct correlation between the increase of tourist function and the increase of the residents' hostility towards visitors of the given destination, therefore, it is often called irritation index (Pearce, 1987 in Királ'ová \& Straka, 2013, p. 43) which was established by Doxey (1975).

Table 2

Description of different values of Defert function

\begin{tabular}{|c|c|l|}
\hline Values of Defert function & Category & \multicolumn{1}{|c|}{ Description } \\
\hline$\langle 0,4\rangle$ & 1 & Practically no tourist activity \\
\hline$(4,10\rangle$ & 2 & Negligible tourist activity \\
\hline$(10,40\rangle$ & 3 & Important but no predominant tourist activity \\
\hline$(40,100\rangle$ & 4 & Predominant tourist activity \\
\hline$(100,500\rangle$ & 5 & Major tourist destination \\
\hline$(500, \infty)$ & 6 & Hypertourist destination \\
\hline
\end{tabular}

Source: Authors processing by using information from Borzyszkowski, Marczak, \& Zarębski (2016); Királ'ová, \& Straka (2013)

\subsection{Schneider index}

Schneider index or tourism intensity rate (TIR) (Smith, \& Krannich, 1998; Dumbrovská, \& Fialová, 2014) measures the number of arrivals at tourist accommodation establishments per 100 regular inhabitants. In case that this index reaches the value of 500 at least, the examined region is well developed (Meyer, Panasiuk, \& Sawińska, 2013). The formula is given by

$$
T I R=\frac{T \cdot 100}{P}
$$

where $T$ is the number of tourists of the region and $P$ is the number of population of the region. Marković, Perić, Mijatov, Doljak, \& Žolna (2017, p. 170) stated that "this indicator reflects the intensity of tourist saturation, which refers to the establishment of a balance between the tourist and general spatial planning for the needs of the local community".

\subsection{Charvat index}

In addition to the two above mentioned indices, to measure the tourism intensity is also used Charvat index, which specifies the number of overnight stays per 100 permanent residents (Skitova, \& Żemła, 2015; Királ'ová, \& Hamarneh, 2016; Marković, Perić, Mijatov, Doljak, \& Žolna, 2017; Rakytova, \& Tomcikova, 2017). It is calculated as 


$$
T c h=\frac{N \cdot 100}{P}
$$

where $N$ is the number of nights spent at tourist accommodation establishments and $P$ is the number of population in the given region. Marković, Perić, Mijatov, Doljak, \& Žolna (2017, p. 170) stated that "number of overnights might be an excellent economic indicator with the possibility of pointing to the positive and negative impact of tourism on the specific area".

Mariot (2001) stated that in 1972, German author Kulinat divided tourism destinations into four groups according to the value of the tourism intensity measured by the number of overnight stays per one inhabitant. It is actually the Charvat index value that is not multiplied by 100 (Table 3). This dividing is appropriate for presenting the diversity of tourism centres within different territories, regions or states. A cartographic interpretation, which Kulinat has also suggested, makes it possible to get an idea of the distribution of tourism in the studied area and visual information about areas of increased concentration of tourism.

Table 3

\section{Destination division based on the Charvat index values}

\begin{tabular}{|c|c|l|}
\hline Number of overnight stays per one inhabitant & Charvat index & \multicolumn{1}{|c|}{ Group } \\
\hline$\langle 0,10)$ & $\langle 0,0.1)$ & $1-$ Tourism destination of the first level \\
\hline$\langle 10,50)$ & $\langle 0.1,0.5)$ & 2 - Tourism destination of the second level \\
\hline$\langle 50,100)$ & $\langle 0.5,1.0)$ & 3 - Tourism destination of the third level \\
\hline$\langle 100, \infty)$ & $\langle 1.0, \infty)$ & 4 - Tourism destination of the fourth level \\
\hline
\end{tabular}

Source: Authors processing by using information from Mariot (2001)

\subsection{Other indicators of tourism intensity}

Dumbrovská, \& Fialová (2014) and Királová, \& Hamarneh (2016) have used additional indicators which measures tourism intensity, namely index of territorial density of tourism (ITD) that is the ratio of the number of bed places in accommodation establishment and number of square kilometre of an entire surface; tourist density rate (TDR) which measures how many tourists are approximately in the destination per day per $100 \mathrm{~km}^{2}$. Besides that, Maggie (2010) used index of land use (ILU). These indicators are calculated by using following formulas:

$$
\begin{aligned}
I T D & =\frac{L \cdot 100}{A} \\
T D R & =\frac{T \cdot 100}{A \cdot 365} \\
I L U & =\frac{T+P}{A}
\end{aligned}
$$

where $L$ is number of bed places in accommodation establishment in, $A$ is the area of a given region in $\mathrm{km}^{2}, T$ is the number of arrivals, and $P$ is the number of population in the studied region.

\section{Results}


Based on our analysis, we obtained several results. First, we studied a correlation between the number of arrivals and the number of bed places. Using Pearson's correlation coefficient and taking into account data from Table 1 we obtained positive correlation $(0.75)$ between mentioned variables and this confirmed the hypothesis that regions with a larger number of visitors also have more beds in accommodation establishments.

Next, we found out which three NUTS III regions of Slovakia have the highest tourism intensity. The results in Table 4 suggest that in 2016, Bratislava Region had the biggest volume of tourism intensity among the surveyed Slovak NUTS III regions. The second position occupied the Zilina region. Within the two regions mentioned above, their position was changed only within the indicator of Defert Function. Calculated values show that there is one extra tourist per inhabitant in the region of Zilina Region than in Bratislava Region. Graph 2 visualizes dividing Slovak NUTS III regions into categories resulting from Table 2. The Presov Region is ranked third within four of the six calculated indicators, but taking into account values of the ITD and $I L U$ indicators the Trnava region is ranked on this place. The positions of the other regions vary and depend on the indicator we take into account. In general, we can say that the region, in which the capital of Slovakia is located, ranked first. The second and third place occupied the regions with the most famous attractions of Slovakia that are the High and Low Tatras, destinations of summer hiking and winter sports, and spas.

Table 4

Indicators of tourism intensity in Slovak NUTS III regions in 2016

\begin{tabular}{|l|c|c|c|c|c|c|}
\hline \multicolumn{1}{|c|}{ Region } & DF & TIR & Tch & ITD & TDR & ILU \\
\hline Bratislava Region & 4.409 & 218.902 & 473.789 & 1.360 & 0.185 & 0.984 \\
\hline Trnava Region & 2.822 & 56.910 & 215.098 & 0.381 & 0.021 & 0.212 \\
\hline Trencin Region & 2.587 & 54.586 & 216.038 & 0.339 & 0.020 & 0.203 \\
\hline Nitra Region & 2.372 & 43.783 & 121.323 & 0.255 & 0.013 & 0.155 \\
\hline Zilina Region & 5.802 & 141.293 & 402.230 & 0.588 & 0.039 & 0.245 \\
\hline Banska Bystrica Region & 3.295 & 79.767 & 247.219 & 0.228 & 0.015 & 0.124 \\
\hline Presov Region & 3.935 & 104.122 & 330.644 & 0.360 & 0.026 & 0.187 \\
\hline Kosice Region & 2.911 & 43.559 & 91.182 & 0.343 & 0.014 & 0.169 \\
\hline
\end{tabular}

Source: Authors calculations

Graph 2

Dividing Slovak NUTS III regions into categories by the value of Defert function in 2016

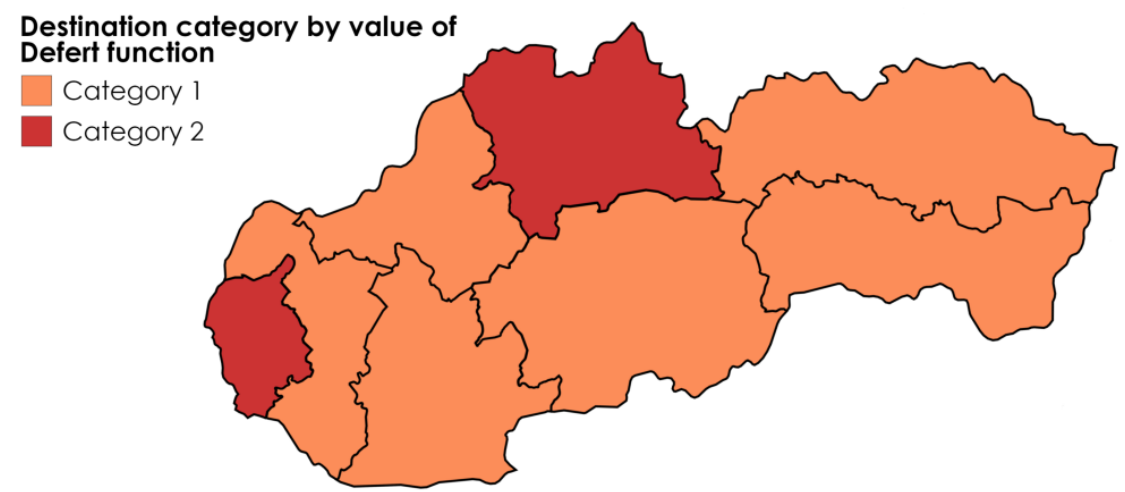

Source: Authors processing based on authors calculations 
Third, we studied whether there has been a positive change in the development of tourism intensity indicators during the period from 2001 to 2016. Table 5 shows that almost all indicators changed in a positive way. Only Defert function, Charvat index, and index of territorial density of tourism recorded negative changes. Specifically, in Trnava Region the number of nights spent at accommodation establishments has dropped by almost 80,000; in Banska Bystrica Region by 150,000; and in Presov Region by 200,000; and thus these changes negatively affected Charvat index. In Kosice Region, the decrease in the number of bed places by almost 16,000 was negatively signed on the Defert function and on the indicator index of territorial density of tourism. Taking into account the difference between the values of the indicators between the years 2016 and 2001, the greatest increase was recorded in the Bratislava region. Changes in other regions have evolved differently.

Table 5

Changes (2016 - 2001) in the development of indicators of tourism intensity in Slovak NUTS III regions

\begin{tabular}{|l|c|c|c|c|c|c|}
\hline \multicolumn{1}{|c|}{ Region } & DF & TIR & Tch & ITD & TDR & ILU \\
\hline Bratislava Region & 1.889 & 118.442 & 266.502 & 0.625 & 0.105 & 0.399 \\
\hline Trnava Region & 0.612 & 12.573 & -17.744 & 0.087 & 0.005 & 0.020 \\
\hline Trencin Region & 0.707 & 18.348 & 84.515 & 0.086 & 0.006 & 0.019 \\
\hline Nitra Region & 0.425 & 16.220 & 41.166 & 0.036 & 0.004 & 0.011 \\
\hline Zilina Region & 1.668 & 63.030 & 99.339 & 0.168 & 0.017 & 0.063 \\
\hline Banska Bystrica Region & 0.016 & 19.897 & -18.586 & -0.002 & 0.004 & 0.012 \\
\hline Presov Region & 0.257 & 15.949 & -37.476 & 0.037 & 0.005 & 0.021 \\
\hline Kosice Region & -2.305 & 8.994 & 4.430 & -0.248 & 0.003 & 0.017 \\
\hline
\end{tabular}

Source: Authors calculations

As we take into account the large regions within surface area, the tourist density rate $(T D R)$ says that there was none tourist on average per day per $100 \mathrm{~km}^{2}$ (Table 4). Therefore, tourism intensity seems to be weak among our studied eight self-governing Slovak regions. For that reason, and taking into account the sustainability criterion, in further research, we will focus on studying smaller municipalities within each NUTS III region.

\section{Conclusion}

At present, Slovakia is lagging behind its competitors mainly in system solutions, in cooperation with entities, professionalism and quality of service, visiting services as a customer care system, in innovation and education. In the development of the product or marketing, current trends and the state of tourism are not often taking into account. This is mainly a consequence of the attitude of a state that has not attributed significant importance to tourism, and therefore tourism has been poorly systemically supported, for example, in the field of legislation, in the field of support for entrepreneurship of small and medium-sized companies (Kuhn, Tomášová, 2011).

The first step in creating a functioning tourism strategy is to identify the current state of tourism, and into this step, we can also include our analysis. Mentioned step requires the cooperation of the main stakeholders, such as regional tourism organizations, destination tourism organizations, Statistical Office of the Slovak Republic, Institute of Informatics and 
Statistics, as well as it is important to take into account research of Slovak Academic Community. The next steps include the determination of measurable goals and concrete activities that will lead to results in a given time horizon. It is also important to optimize the roles of individual entities and important stakeholders in tourism policy at national, regional and local levels. The role of the state is to financially and legally support the above-mentioned organizations and ensure the cooperation between the destinations and the central planning authorities of the development of the tourism sector, which is the Ministry of Transport and Construction of the Slovak Republic.

Regional specificity and variability predetermine the Slovak area for the development of tourism, which has become increasingly popular in recent years. However, there are differences between the regions in terms of the material and technical basis, which is a precondition for the tourism development.

In this paper, we assessed and visualized the tourism intensity in the eight NUTS III regions of Slovakia. We confirmed the hypothesis that regions with a larger number of visitors also have more beds in accommodation establishments. In addition, we have several important findings connected with the surveyed Slovak NUTS III regions resulting from the calculated indicators of tourism intensity, namely from Defert index $(D F)$, tourism intensity rate $(T I R)$, Charvat index $(T c h)$, index of territorial density of tourism (ITD), tourist density rate $(T D R)$, and index of land use $(I L U)$.

First, in 2016, Bratislava Region had the biggest volume of tourism intensity; the second position occupied the Zilina Region; and Presov Region ranked third. It means the most attractive destination for tourists is the region where the capital city of Slovakia is situated, and regions where High and Low Tatras are.

Second, we found out that there has been a positive change in the development of almost all tourism intensity indicators during the period from 2001 to 2016. The greatest increase was recorded in the Bratislava region. Changes in other regions have evolved differently and negative changes were caused mostly by the decline of the number of nights spent at accommodation establishments and of the number of bed places in the surveyed regions. Based on the values of the calculated indicators, it seems that Slovakia still has the opportunity to develop the tourism sector in all regions.

Third, because of the low values of the tourist density rate we should address the description of smaller territorial units within each NUTS III region. In this case, it is also appropriate to focus on the sustainability criterion which "becomes a rather challenging topic for researchers and academics" (Carrillo, \& Jorge, 2017, p. 97). Királ'ová, \& Hamarneh (2016) state that taking this criterion into account it is possible to avoid potential negative impacts on the destination. The concept of responsible tourism will help improve the quality of life of local people, socio-economic benefits, and holiday experiences; and ensure the protection of natural resources in the chosen destination (Spenceley, et al., 2002, in Mathew, \& Sreejesh, 2017).

Finally, we can point out that our analysis can be practically applied in the creation of tourism development strategy, and can be helpful for tourism policy-makers. Very important is also the cooperation of all stakeholders. These recommendations coincide with the proposals of the authors Maggi (2010), Hontus (2015), Királ'ová, \& Hamarneh (2016), Bucher, \& Nováková (2015), Skitova, \& Żemła (2017). 


\section{Acknowledgements}

This publication is an output from the research grant VEGA No: 1/0470/18 and the research grant VEGA No: 1/0945/17.

\section{References}

Bucher, S., \& Nováková, Š. (2015). Territorial Aspects of Regional Identity and Respondents' Identification with the Region and Place: Case Study of Slovakia1. Eastern European Countryside, 21(1), 81-109.

Carrillo, M., \& Jorge, J. M. (2017). Multidimensional analysis of regional tourism sustainability in Spain. Ecological Economics, 140, 89-98.

Che, D. (2017). Tourism Geography. Oxford bibliographies in geography. Oxford: Oxford University Press.

Eurostat database. (2018). http://ec.europa.eu/eurostat/data/database

Doxey, G. (1975). A Causation Theory of Visitor-Resident Irritants: Methodology and Research Inferences. Proceedings of the Travel Research Association Sixth Annual Conference, San Diego, 195-198.

Dumbrovská, V., \& Fialová, D. (2014). Tourist intensity in capital cities in central Europe: Comparative analysis of tourism in Prague, Vienna and Budapest. Czech Journal of Tourism, 3(1), 5-26.

Fil’arská, J., Vozárová, I. K., \& Kotulič, R. (2017). Analysis of Tourism in the Slovak Republic in the Period after Accession to the European Monetary Union. Journal of Environmental Management \& Tourism, 6(22), 1157-1165.

Gajdošíková, Z., Gajdošík, T., Kučerová, J., \& Magátová, I. (2016). Reengineering of tourism organization structure: The case of Slovakia. Procedia-Social and Behavioral Sciences, 230, 405-412.

Gauche, M. (ed.). (2017). Tourism intensity at a local level: environmental pressure or preservation factor? La Défense: General Commission for Sustainable Development. http://www.statistiques.developpementdurable.gouv.fr/fileadmin/documents/Produits_editoriaux/Publications/Datalab/2017/datalab17-la-fonction-touristique-des-territoires...mars2017-anglais.pdf

Gregorová, B. (2014). BARBORSKÁ CESTA-NOVÝ PRODUKT CESTOVNÉHO RUCHU?. Geografické informácie, 1, 34-43.

Hagyari, P., Bačík, R., \& Fedorko, R. (2016). Analysis of the Key Factors of Reputation Management in Conditions of City Marketing. Polish Journal of Management Studies, 13(1), 69-80.

Harrison, D. (1992). Tourism and the less developed countries. London: Belhaven Press.

Hontus, A. C. (2015). Analysis of Tourist Traffic in Slanic Prahova to Develop Tourism in the Area. Analysis, 15(3), 159-166

Hroncova, I., Birknerova, Z., \& Janovska, A. et al. (2012) Selected Factors of Consumer Behaviour in Slovakia. Proceedings of the Conference on Management 2012 - Research in Management and Business in the Light of Practical Needs. Presov, Slovakia, 322-327.

Királ'ová, A., \& Hamarneh, I. (2016). Riverside tourism in an urban area - How can it work?. Geographical Information, 20(2), 507-522.

Királ'ová, A., \& Straka, I. (2013). Vliv globalizace na marketing destinace cestovního ruchu. Praha: Ekopress. 
Királová, A., \& Pavlíčeka, A. (2015). Development of social media strategies in tourism destination. Procedia-Social and Behavioral Sciences, 175, 358-366.

Kuhn, I., \& Tomášová, P. (2011). Úvod do destinačného manažmentu. Bratislava: Sekcia cestovného ruchu, Ministerstvo dopravy, výstavby a regionálneho rozvoja SR.

Kulinat, K. (1972). Die Typisierung von Fremdenverkehrsorten. Göttinger Geographische Abhandlungen, 60, 521-538.

Louis, J. M. (2004). Methodologies and Procedures for Filling Major Gaps in Data: Tourist penetration

rate. http://www.caricomstats.org/Files/Meetings/SocialandCensus/TOURISTPENETRATIONRA TE-StLucia.pdf

Maggi, E., \& Fredella, F. L. (2010). The carrying capacity of a tourist destination. The case of a coastal Italian city. 50th Congress of the European Regional Science Association: Sustainable Regional Growth and Development in the Creative Knowledge Economy, Sweden, 1-18.

Mariot, P. (2001). Príspevok k typizácii stredísk cestovného ruchu. Geografický časopis, 53(4), 307-319.

Marković, S., Perić, M., Mijatov, M., Doljak, D., \& Žolna, M. (2017). Application of Tourist Function Indicators in Tourism Development. Journal of the Geographical Institute'Jovan Cvijic'SASA, 67(2), 163-178.

Mathew, P. V., \& Sreejesh, S. (2017). Impact of responsible tourism on destination sustainability and quality of life of community in tourism destinations. Journal of Hospitality and Tourism Management, 31, 83-89.

Meyer, B., Panasiuk, A., \& Sawińska, A. (2013). Analysis of the Service Potential of the Pomeranian Way of St. James (in the Area of the West-Pomeranian Voivodship). The Pomeranian Way of St James-Culture, Religion and Tourism. Greifswald: Forum für Regional-, Freizeit- und Tourismusforschung an der Universität Greifswald, 23-39.

Pearce, D. G. (1987). Tourism today. A geographical analysis. London: Longman Scientific \& Technical.

Pásková, M., \& Zelenka, J. (2002). Výkladový slovník cestovního ruchu. Praha: Ministerstvo pro místní rozvoj.

Potts, T. D., \& Uysal, M. (1992). Tourism intensity as a function of accommodations. Journal of Travel Research, 31(2), 40-43.

Rakytova, I., \& Tomcikova, I. (2017). Assessing Sustainability in Mountain Tourism of Demanovska Valley, Slovakia. European Journal of Geography, 8(2), 6-23.

Sezgin, M., \& Gumus, M. (2016). The Evaluation of Beysehir Lake National Park (KonyaTurkey) in the Framework Ecotourism. Forest, 14, 16-8.

Skitova, N., \& Żemła, M. (2017). The role of tourism in local development strategies on the example of selected tourism comunnities in Malopolska region, Poland. Current Issues of Tourism Research, 5(2), 12-19.

Slovakia.travel portal. (2015). http://slovakia.travel/

Smith, M. D., \& Krannich, R. S. (1998). Tourism dependence and resident attitudes. Annals of tourism research, 25(4), 783-802.

Spenceley, A., Relly, P., Keyser, H., Warmeant, P., McKenzie, M., Mataboge, A., ... \& Seif, J. (2002). Responsible Tourism Manual for South Africa, Department for Environmental Affairs and Tourism, July 2002. Responsible Tourism Manual for South Africa, 2(3).

Statistical Office of the Slovak Republic database. (2018). http://datacube.statistics.sk/ Štefko, R., Bačík, R., \& Fedorko, R. (2017). City Marketing and Its Impact on Income Sources of the Local Government. Polish Journal of Management Studies, 15(1), 244-254. Štefko, R., Királ'ová, A., \& Mudrík, M. (2015). Strategic marketing communication in pilgrimage tourism. Procedia-Social and Behavioral Sciences, 175, 423-430. 
Štefko, R., \& Šteffek, V. (2017). A Study of Creative Industry Entrepreneurial Incubation.

Polish Journal of Management Studies, 15(2), 250-261.

UNWTO. (2005). Making Tourism More Sustainable-A Guide for Policy Makers. New York: UNEP UNWTO.

UNWTO. (1981). Saturation of Tourist Destinations: Report of the Secretary General. Madrid: World Tourism Organisation.

\section{prof. Ing. Róbert Štefko, Ph.D.}

Department of Marketing and International Trade

Faculty of Management

University of Prešov

Slovakia

Email: robert.stefko@unipo.sk

Róbert Štefko is the Dean of the Faculty of Management of University of Prešov, where in the economic field of study Management, he is the guarantor of bachelor's, master's and doctoral study programmes. Up to now, he has been a member of nine faculty and university scientific boards (seven faculty and two university scientific boards) at universities in the Czech Republic, Slovakia and Poland. He is the Chairperson of the Scientific Board of the Faculty of Management of University of Prešov.

\section{Mgr. Petra Vašaničová}

Department of Mathematical Methods and Managerial Informatics

Faculty of Management

University of Prešov

Slovakia

Email: petra.vasanicova@gmail.com

Petra Vašaničová is a Ph.D. student at the Faculty of Management, University of Prešov. Her research interest is the study of how tourism activity among European countries is interconnected with each other, how to predict financial distress of companies in the tourism sector and how can network theory help us to understand interconnectedness of tourism activity in Europe.

doc. Mgr. Eva Litavcová, PhD.

Department of Mathematical Methods and Managerial Informatics

Faculty of Management

University of Prešov

Slovakia

Email: eva.litavcova@unipo.sk

Eva Litavcová is an Associate professor at the Faculty of Management of the University of Prešov. She is a member of the Slovak Statistical Society. Her research interests lies in applied statistical methodology and quantitative methods in general (in tourism analysis, ecology, biology, economics, finance, management and psychology). Within tourism, her research concentrates on visitor surveys: methods for the collection, analysis, presentation and 
interpretation of quantitative information obtained from visitors to recreational and tourist venues.

Ing. Sylvia Jenčová, PhD.

Department of Finance

Faculty of Management

University of Prešov

Slovakia

Email: sylvia.jencova@unipo.sk

Sylvia Jenčová is an Associate professor in the Department of Finance, Faculty of Management, University of Prešov, since 2008. Scientific research (with publication) has focused on financial analysis, primarily in the area of financial management, financial modeling, managerial economics, and is dedicated to an assay method, as well as selected macroeconomic problems. She lectured in Managerial Economics and International Trade and Business at the Business Institute in Prague. 